\title{
Ethnobotanical Survey of Medicinal Plants Used Against Fungal Infections in Prefecture of Sotouboua Central Region, Togo
}

\author{
Teou Alfa \\ Kokou Anani \\ Yao Adjrah
}

Centre de Recherche et de Formation sur les Plantes Médicinales (CERFOPLAM), Université de Lomé, Laboratoire de Microbiologie et de Contrôle de Qualité des Denrées Alimentaires (LAMICODA), Université de

Lomé, Ecole Supérieure des Techniques Biologiques et Alimentaires (ESTBA), Université de Lomé , Lomé - Togo.

\section{Komlan Batawila}

Centre de Recherche et de Formation sur les Plantes Médicinales (CERFOPLAM), Université de Lomé, Laboratoire de Botanique et de Physiologie végétale, Facultés des Sciences de la Vie et de la Terre (SVT), Université de Lomé, Lomé - Togo.

\section{Yaovi Ameyapoh}

Centre de Recherche et de Formation sur les Plantes Médicinales (CERFOPLAM), Université de Lomé, Laboratoire de Contrôle de Qualité des Denrées Alimentaires (LAMICODA), Université de Lomé, Ecole Supérieure des Techniques Biologiques et Alimentaires (ESTBA), Université de Lomé, Lomé - Togo.

Doi: 10.19044/esj.2018.v14n3p342 URL:http://dx.doi.org/10.19044/esj.2018.v14n3p342

\begin{abstract}
Plants are a major source of active ingredients and are for that fact used to treat many diseases such as fungal infections. The objective of this study was to identify the plants used in traditional medicine to treat fungal diseases in the prefecture of Sotouboua. An ethnobotanical survey was conducted among healers, elderly and knowledgeable villagers. A semi structured questionnaire and pictures showing common and easily recognizable fungal infection symptoms were used to support a live interview. During this study, 37 plant species belonging to 20 families have been identified. Fabaceae were the most represented family ( 7 species). The most used parts were leaves (43, $24 \%)$ followed by the roots $(18,91 \%)$. The decoction is the preferred method of preparation while the oral route is the main route of administration.
\end{abstract}


Sotouboua prefecture in Togo has significant plant biodiversity that is used by dwellers in the management of fungal diseases.

Keywords: Ethnobotanical survey, medicinal plants, fungal infections, Prefecture of Sotouboua, Togo

\section{Introduction}

Traditional medicine has been used for centuries by herbalists, healers, spiritualists, hunters and farmers to treat various categories of human diseases (Alqasim, 2013).This traditional knowledge, transmitted from generation to generation is a result of thousands of experiences made by people while being in connection with their nature. In the rural areas in Africa, about $80 \%$ of the population depends on traditional medicine for their health needs (Ngono, 2011). This intensive use of traditional medicine is due to its affordability, availability, accessibility and acceptability (WHO, 2000; Gbadamosi, 2014). However, scientific proof from trials done to assess the preventive and efficacy of traditional medicine products and practices is limited. For that reason, ethnobotanists, medicinal chemists, pharmacologists, economic botanists and ethnobiologists all over the globe have been actively working to gather records to preserve indigenous therapeutic plants and to hunt novel bioactive compounds (leads), which could be developed as an effective drugs (Cowan, 1999; Pushpangadan, 1984). New molecules are needed in the management of various infectious diseases. Fungal infections are various, they range from superficial infections (ringworm) a major source of morbidity affecting hair (tinea), nail (onychomycoses), skin (herpes vine) and mucosa (aphthae) to systemic fungal infections (meningitis; pneumonia and bronchopneumonia) that are life-threatening (vicente,2003). These diseases affecting immunocompromised patients (HIV), premature infants, cancer patients receiving chemotherapy, transplant and burn patients (Garraffo, 2003) and healthy individuals, especially third world children suffering from poor sanitation conditions are steadily increasing (Borman et al.,2007). Although seemingly a large amount of drugs for the treatment of fungal infections are commercially available, only few of them are really effective antifungals. Many treatments have side effects or are actually toxic (Amphotericin B); are fungistatic and not fungicidal (azoles), or are responsible for inducing the development of resistance (Pfaller et al., 2011). Fungal diseases are then appearing to be one of the most challenging domain where new molecules are urgently needed and plants are most expected to be the source of these new molecules (Ahmed, 2008; Simbo, 2010; Gruca, 2015). Ethnobotanical investigations of plants used against fungal infections have been reported for parts of Togo (Batawila, 2002) and parts of the adjacent prefectures Sokodé and Tchamba (Tittikpina, 2013) but no 
investigation has ever been carried out in Sotouboua. It is therefore necessary to carry out a survey to document the plants used against fungal infections in Sotouboua.

\section{Method \\ Study area}

Togo is a country of $56600 \mathrm{~km}^{2}$ situated on the West-African coast. He is limited by Benin in the East, Ghana in the West, Burkina Faso to the North and Atlantic Ocean in the South. Togo is divided in five administrative and economic areas which are from south to north: region Maritime; region des Plateaux; region central, region de la Kara and region des Savanes. The central region is covering $13.470 \mathrm{~km}^{2}$ with a population of $494000 \mathrm{hts}$. Situated between the parallel $8^{\circ}$ and $9^{\circ} 15$ of the north latitude and the meridians $0^{\circ} 15$ and $1^{\circ} 35$ of the longitude east, the region is divided in 5 prefectures: Prefecture de Sokodé; Prefecture de Tchamba; Prefecture de Blitta and Prefecture de Sotouboua which is our study area. On the climatic plan the region enjoys with a hot and wet tropical climate. Rains extend over six months (from May till October). The August and September are the rainiest. The pluviometric totals are situated between 1200 and $1500 \mathrm{~mm}$ a year. The temperatures vary generally between 20 and $30^{\circ} \mathrm{C}$ with minima between November- January and maxima in February-March. Sotouboua is divided in to two plains by the national park Fazao. The park witch is a reserve of fauna is also a reserved zone of flora as bush fires and trees cutting are strictly controlled. The mountainous zones are covered by forests while plains are dominated by savannas with denser and more linear ligneous populating along rivers.

Almost all the ethnic groups of the country (about forty) are represented in Sotouboua but the major ethnic groups are: Kabyè; Kotokoli and Losso. The economy is essentially based on the agriculture. The trade and fishing are less represented whereas the branch of industry is almost nonexistent. 


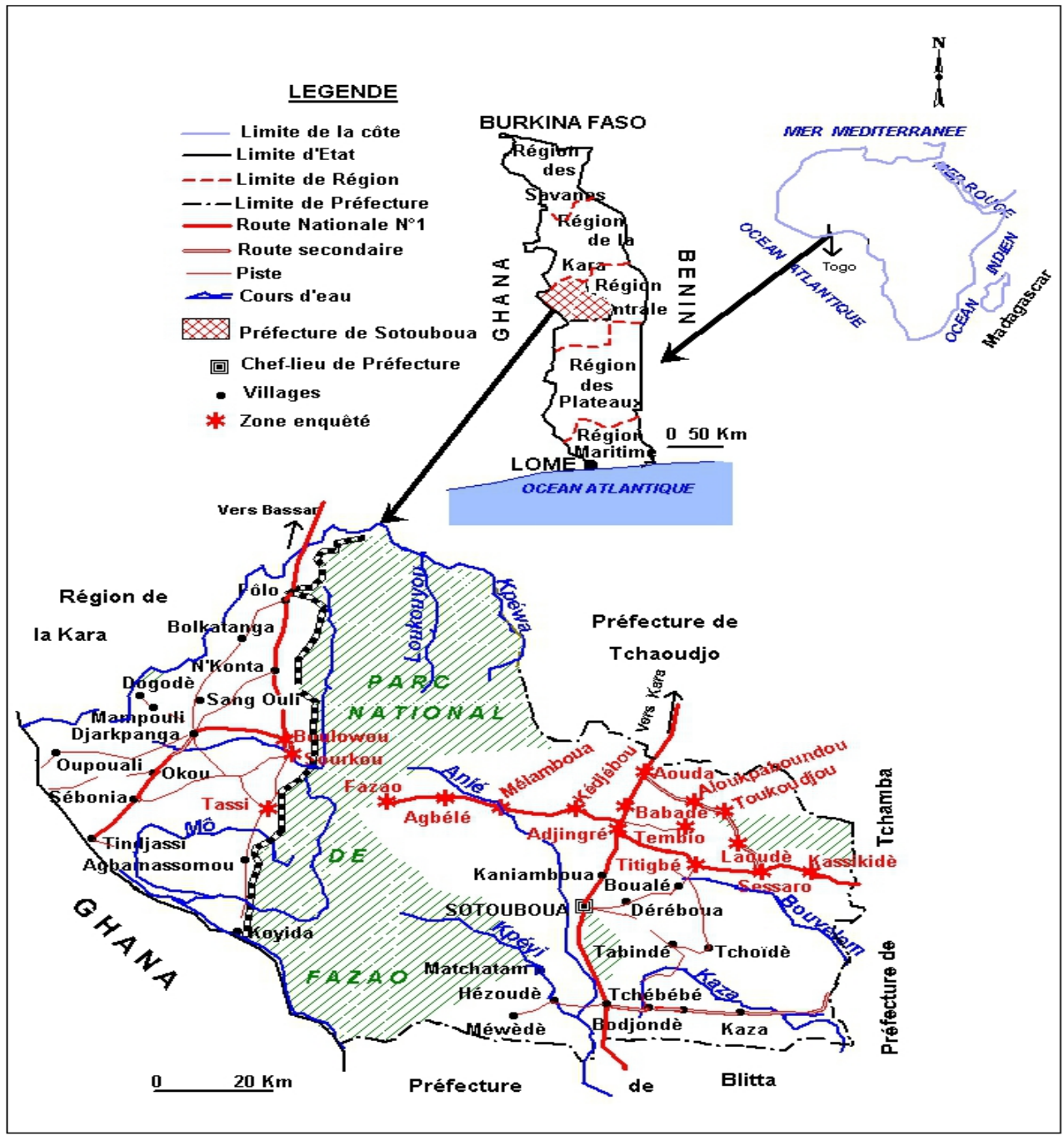

Source : Direction de la Statistique de I/nformation et de la Documentation, (D S ID).

\section{Sample collection}

An ethnobotanical survey was carried out in Prefecture de Sotouboua to identify plants used to treat fungal diseases in that area. During this survey direct interviews have been conducted among traditional healers, community elders and people having knowledge of traditional medicine. As Raveesha and co- workers in 2015, pictures showing common and easily recognizable fungal diseases (tinea, herpes vine and aphthae) has been used to make interviewers aware of the symptoms with regard to the medicinal plants used to treat such symptoms.

The person interviewed is included if only he can fill these 3 criteria: 1- he has recognized at least one infection symptom. 2- He knows at least one 
plant that can be used to treat the recognized infection. 3- He can identify and collect a specimen of the cited plant.

The data was collected in local language (Kabyè and Kotokoli) through a semi-structured questionnaire and open-ended conversations. At each interview, the following data were gathered and set on an identity card: Date and place of gathering information; age and sex; profession; education; vernacular name of the plant; disease healed; Part of the plant being used; mode of preparation and administration. Then the plant specimen collected is pressed, labelled with its local name and send to the vegetal physiology laboratory of Université de Lomé for identification.

\section{Data analysis}

All data collected has been analyzed using Excel software. The plant species were listed in alphabetical order by scientific name, family name, local name, used value (UV), plants parts used, mode of preparation and administration. The UV of the species of plants being utilized was evaluated using the formula: UV = Number of times a particular species was mentioned/Number of persons interviewed.

\section{Results}

\section{Informants}

A total of 226 informants aged from 30 to 70 years have participated in this study. Major informants are female. Majority of the interviewers were aged around 50-60 years. Most of the interviewers have attempted 6 or 10 years education level. Significant portion of informants were local old people (Table 1).

Table 1: Socio demographic data of informants

\begin{tabular}{|c|c|c|c|}
\hline Variable & Categories & Number of person & percentage \\
\hline \multirow{3}{*}{ Gender } & Male & 95 & 42,03 \\
\cline { 2 - 4 } & female & 131 & 57,96 \\
\hline \multirow{2}{*}{ Age } & $30-39$ & 39 & 17,25 \\
\cline { 2 - 4 } & $40-49$ & 113 & 50 \\
\cline { 2 - 4 } & $50-59$ & 50 & 22,12 \\
\hline \multirow{2}{*}{$\begin{array}{c}\text { Educational } \\
\text { background }\end{array}$} & $60 \leq$ & 24 & 10,61 \\
\cline { 2 - 4 } & Illiterate & 109 & 48,23 \\
\cline { 2 - 4 } & 10 years education school & 84 & 37,16 \\
\cline { 2 - 4 } & 13 years education school & 28 & 12,38 \\
\hline
\end{tabular}




\section{Medicinal plants diversity}

In this study, 37 plant species distributed in 20 families were identified as being used to treat fungal infections. The most representative family was the Fabaceae with 7 species, followed by Rubiaceae with 4 species and Caesalpiniacea; Combretaceae with 3 species each. Other families have one or two species.

Table 2: Medicinal plants used in the treatment of fungal infections.

\begin{tabular}{|c|c|c|c|c|c|c|c|}
\hline Scientific name & Family & Local name & $\mathrm{UV}$ & Disease & part used & Preparation & Administration \\
\hline $\begin{array}{c}\text { Acanthospermum } \\
\text { hispidum DC }\end{array}$ & Asteraceae & Kpangsoyè & 0,02 & Aphtae & $\begin{array}{c}\text { Whole } \\
\text { plant }\end{array}$ & Decoction & Oral \\
\hline Agave sisalana Perrine & Agavaceae & Kolgragou felgou & 0,005 & Aphtae & Root & Decoction & Oral \\
\hline $\begin{array}{l}\text { Anogeissus leiocarpus } \\
\text { (DC.) Guill. \& Perr. }\end{array}$ & Combretaceae & Kolou & 0,01 & Aphtae & Leaves & Decoction & Oral \\
\hline Annona senegalensis Pers & Annonaceae & Tchoutchourè & 0,01 & Aphtae & Leaves and Fruit & Decoction & Oral \\
\hline Blighia sapida K.D. Koenig & Sapindaceae & Kpiziyè & 0,075 & $\begin{array}{c}\text { Aphtae } \\
\text { haerpes } \\
\text { vine }\end{array}$ & $\begin{array}{l}\text { Fruit or } \\
\text { Bark }\end{array}$ & Calcinat & $\begin{array}{l}\text { Applied } \\
\text { Locally }\end{array}$ \\
\hline Burkea africana Hook & Fabaceae & Tchangbali & 0,01 & Aphtae & Leaves & Decoction & Oral \\
\hline Cajanus cajan (L.) Huth & Fabaceae & Assongoyè & 0,02 & aphtae & $\begin{array}{c}\text { Whole } \\
\text { plant }\end{array}$ & Decoction & Oral \\
\hline Chassalia kolly (Schumach.) Hepper & Rubiaceae & Tiyah & 0.06 & Tinea & Roots & Paste & Applied locally \\
\hline $\begin{array}{l}\text { Cochlospermum } \\
\text { planchonii Hook }\end{array}$ & Cochlospermaceae & Kalantcheyah & 0,001 & aphtae & Leaves & Decoction & Oral \\
\hline Daniellia oliveri (Rolfe) Hutch. \& Dalziel & Caesalpiniaceae & Hemou & 0,055 & aphtae & $\begin{array}{l}\text { Leaves and } \\
\text { bark }\end{array}$ & Maceration & Oral \\
\hline $\begin{array}{l}\text { Detarium microcarpum } \\
\text { Guill. \& Perr. }\end{array}$ & Caesalpiniaceae & Kpayè & 0,01 & aphtae & Bark & Maceration & Oral \\
\hline Ficus sur Forssk & Moraceae & Kaliay & 0,05 & Tinea ; & Leaves & & $\begin{array}{l}\text { Applied } \\
\text { Locally }\end{array}$ \\
\hline
\end{tabular}




\begin{tabular}{|c|c|c|c|c|c|c|c|}
\hline & & & & $\begin{array}{l}\text { Herpes } \\
\text { vine }\end{array}$ & & & \\
\hline Fucus exasperata Vahl & Moraceae & Laalayou & 0,005 & aphtea & Leaves & Decoction & Oral \\
\hline Gardenia ternifolia J.Ellis & Rubiaceae & Kaou & 0,005 & tinea & Root & Calcinat & $\begin{array}{l}\text { Applied } \\
\text { Locally }\end{array}$ \\
\hline Heliotropium indicum $\mathrm{L}$. & Boraginaceae & Soucondiè & 0,02 & aphtea & $\begin{array}{c}\text { Whole } \\
\text { plant }\end{array}$ & Decoction & Oral \\
\hline $\begin{array}{c}\text { Holarrhena floribunda } \\
\text { (G.Don) T.Durand \& Schinz }\end{array}$ & Apocynaceae & Kororo & 0,005 & aphtea & Leaves & Decoction & Oral \\
\hline Hymenocardia acida & Euphorbiaceae & KpaiKpai & 0,15 & aphtea & Leavess & Decoction & Oral \\
\hline Hyptis suaveolens (L.) Poit. & Lamiaceae & Pinbinè & 0,005 & aphtea & Root & Maceration & Oral \\
\hline Jatropha curcas L. & Euphorbiaceae & Essogbalou & 0,005 & aphtea & Leaves & decoction & Oral \\
\hline Lophira lanceolata Van Tiegh. ex Keay & Ochnaceae & Tabsomang & 0,025 & $\begin{array}{l}\text { Herpes } \\
\text { vine }\end{array}$ & Stem & rubbing & $\begin{array}{l}\text { Applied } \\
\text { Locally }\end{array}$ \\
\hline Maranthes kerstingii (Engl.) Prance & Chrisobalanaceae & Poundoulayzay & 0,02 & aphtea & Leaves & Decoction & Oral \\
\hline $\begin{array}{c}\text { Maytenus } \\
\text { senegalensis (Lam.) Exell }\end{array}$ & celastraceae & Liakpangsoyè & 0,01 & aphtea & Leaves & decoction & Oral \\
\hline $\begin{array}{c}\text { Sarcocephalus latifolius } \\
\left(\mathrm{Sm}_{.}\right) \text {E.A.Bruce. }\end{array}$ & Rubiaceae & Kayou & 0,055 & aphtea & Root & Decoction & Oral \\
\hline $\begin{array}{l}\text { Parinari curatellifolia } \\
\text { Planch. ex Benth. }\end{array}$ & Chrysobalanaceae & Malay & 0,03 & aphtea & Leaves & decoction & Oral \\
\hline Parkia biglobosa (Jacq.) R.Br. ex G.Don & Fabaceae & Soulou & 0,015 & aphtea & Bark & decoction & Oral \\
\hline Paullinia pinnata $L$. & Sapindaceae & Adjandj kpouzou & 0,025 & aphtea & $\begin{array}{c}\text { aerial } \\
\text { part }\end{array}$ & decoction & Oral \\
\hline $\begin{array}{l}\text { Piliostigma thonningii } \\
\text { (Schum.) Milne-Redh. }\end{array}$ & Caesalpiniaceae & Pambakou & 0,025 & $\begin{array}{c}\text { Aphtea } \\
\text { Herpes } \\
\text { vine }\end{array}$ & Root & decoction & Oral \\
\hline
\end{tabular}




\begin{tabular}{|c|c|c|c|c|c|c|c|}
\hline $\begin{array}{l}\text { Pseudocedrela kotschyii } \\
\text { (Schweinf.) Harms }\end{array}$ & Meliaceae & Helitétéwiyé & 0,045 & aphtea & Root & Maceration & Oral \\
\hline Pteleopsis suberosa Engl. et Diels & Combretaceae & Kézinzinang & 0,187 & aphtea & $\begin{array}{c}\text { Leaves and } \\
\text { bark }\end{array}$ & decoction & Oral \\
\hline $\begin{array}{c}\text { Pterocarpus erinaceus } \\
\text { Poir. }\end{array}$ & Fabaceae & Tém & 0,095 & $\begin{array}{c}\text { Tinea } \\
\text { Herpes } \\
\text { vine }\end{array}$ & latex & & $\begin{array}{l}\text { Applied } \\
\text { Locally }\end{array}$ \\
\hline Securinega virosa (Roxb. ex Willd.) Baill. & Phyllanthaceae & Tchaakatchaka & 0,06 & aphtea & $\begin{array}{c}\text { aerial } \\
\text { part }\end{array}$ & decoction & Oral \\
\hline $\begin{array}{c}\text { Stereospermum kunthianum } \\
\text { Cham. }\end{array}$ & Bignoniaceae & Essogbalou & 0,005 & $\begin{array}{c}\text { Herpes } \\
\text { vine }\end{array}$ & leaves & decoction & Oral \\
\hline Tamarindus indica L. & Fabaceae & Nidié & 0,025 & aphtea & leaves & decoction & Oral \\
\hline $\begin{array}{c}\text { Terminalia avicennioides } \\
\text { Guill. \& Perr. Fl. Seneg. Tent. }\end{array}$ & Combretaceae & Koyèkouloumryè & 0,025 & aphtea & $\begin{array}{c}\text { Aerial } \\
\text { part }\end{array}$ & Decoction & Oral \\
\hline Vernonia cinerea $(\underline{\text { L. }})$ Less. & Asteraceae & Kogbèdiyè & 0,04 & aphtea & $\begin{array}{c}\text { Aerial } \\
\text { part }\end{array}$ & decoction & Oral \\
\hline Xeroderris stuhlmannii (Taub.) Mendonça\&E.C.Sousa & Fabaceae & Kpodougboou & 0,005 & aphtea & $\begin{array}{c}\text { aerial } \\
\text { part }\end{array}$ & decoction & Oral \\
\hline $\begin{array}{l}\text { Zanthoxylum zanthoxyloides } \\
\text { (Lam.) Zepern. \& Timler, }\end{array}$ & Rutaceae & Kolgragu felgou & 0,01 & aphtea & $\begin{array}{c}\text { aerial } \\
\text { part }\end{array}$ & Maceration & Oral \\
\hline
\end{tabular}


These plants listed belongs to divers botanical families as presented by (Figure 1)

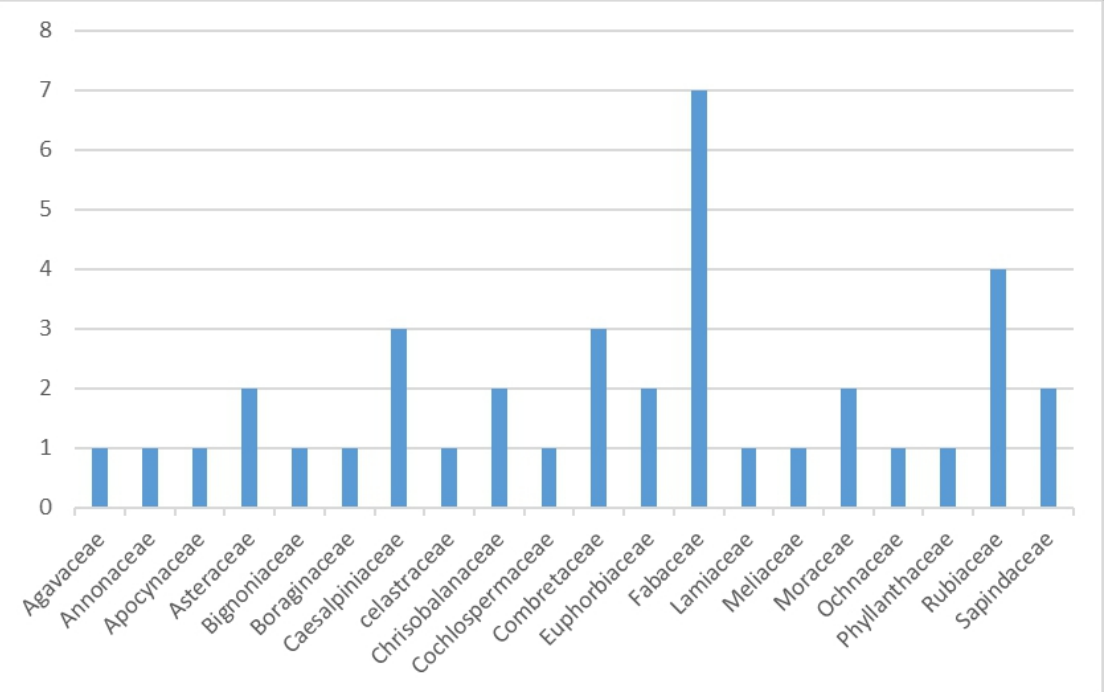

Figure1: Families of plants used in the treatment of fungal infections.

\section{Plant parts used in the treatment of fungal infections}

Percentages of plant part used were calculated as the ratio between the number of plants in which a certain part is used and the total number of plants. Leaves are the major plant parts used for the treatment of fungal infections $(43,24 \%)$ followed by root $(18,91 \%)$ and aerial parts $(16,21 \%)$.

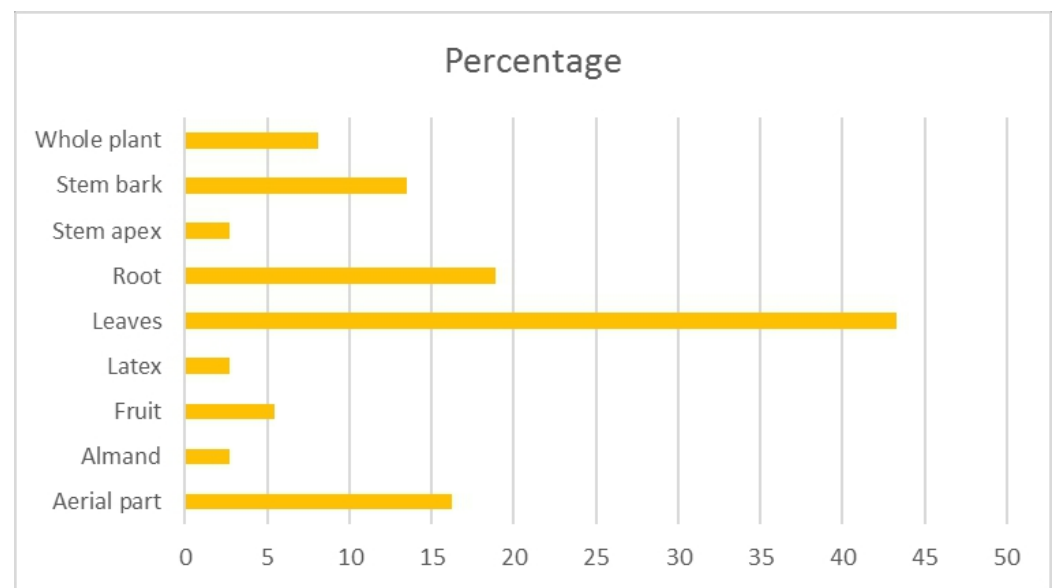

Figure 2. Plant parts used in the treatment of fungi infections. 


\section{Preparation and administration of plants used in the treatment of fungal infections.}

Different mode of preparation were usually used but the most cited are decoction and maceration. The prepared remedies are administrated by oral route or topical application.

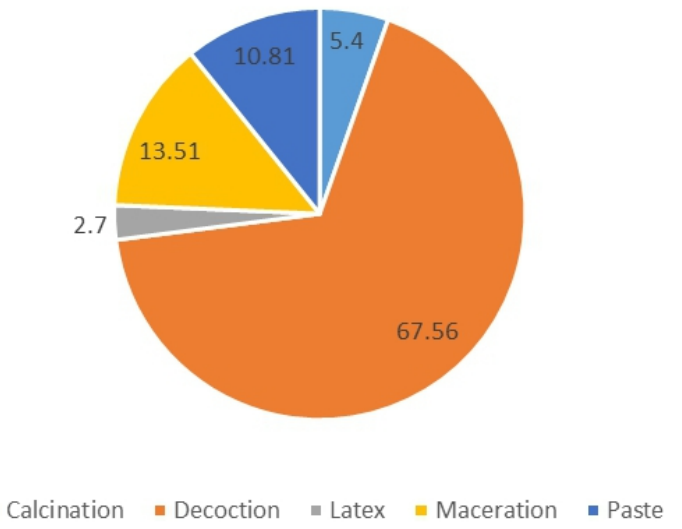

Figure 3: Percentage distribution of plants preparation used in the treatment of fungal infections.

The oral route is the most used in the treatment of fungal infections $(78 \%)$ while the external use represent $(22 \%)$.

\section{Discussion}

This study was aiming to check off the medicinal plants used to cure fungal infections. An ethnobotanical survey has been carried out in many villages of Prefecture de Sotouboua in the central region of Togo. A total of 226 community elders, traditional healers and people having knowledge of medicinal plants participated in the study. There were131 (57, $97 \%)$ females and only $95(42,03 \%)$ males. This finding is contrary to the general tendency where males are in the majority (Simbo, 2010; Anup et al., 2014; Gbadamosi et al., 2014; Gbekle et al., 2015). The large majority of females in our study is due to the fact that most of the symptoms shown on the photographs used for the survey (Aphthae, herpes vine; Tinea) are related to infants. Women being in charge of children's care are more knowledgeable to plants used against children's diseases. Similar trend regarding the majority of females is also reported in Morocco (Mustapha et al., 2012); in Nigeria (Shosan et al., 2014); in South Africa (Otang et al. 2011). The majority of respondents are around 50 years old; this is because people of this age are so mature and responsible to enjoy elderly's confidence regarding the community secret holding. As such they are depository of the knowledge of plants used to cure diseases and ailments in the community. 
The study showed that the majority of interviewers $(51,77 \%)$ are literate. Interestingly, the frequency of use of medicinal plants was inversely related to the level of education of the interviewed population; illiterate: 48 , 23\%; 6 years education school: $37.16 \%$; 10 years education school: $12.38 \%$ and 13 years education school: $2.21 \%$. The people who studied are more inclined towards the modern medicines resulting in loss of valuable herbalbased knowledge (Mustapha et al., 2012).

A total of 37 plant species belonging to 20 families were reported as remedies for the treatment of fungal infections (Table 1). This is indicative of a considerable diversity and abundance of plant species used in the treatment of fungal infections in the study area. Some authors has reported similar biodiversity findings: Otang et al. in 2012 has reported 33 plant species distributed in 26 families and 32 genera as being used to treat one or more of the opportunistic fungal infections in HIV/AIDS patients in the Amathole District of the Eastern Cape Province, South Africa. In Pakistan Sheher et al. in 2013 has reported 50 plants belonging to 33 families during a literature survey on plants used to treat skin infections.

The most representative plant family was: Fabaceae ( 7 species) followed by Rubiaceae with 4 species and Caesalpinaceae; Combretaceae with 3 species each and Asteraceae; Chrisobalanaceae; Moraceae and Sapindaceae with 2 species each. Other families are represented by one specie (fig 1). Although the active chemical compounds (and their modes of action) of the surveyed plants were largely unknown, it is plausible regarding the long period of usage that the plant families contain bioactive secondary metabolites that work against fungal infections. For example, previous studies reported that Fabaceae and Caesalpinaceae are containing alkaloids, anthocyanin, saponosides, tanins (Maloueki et al., 2015). The family Combretaceae is reach in Tannin; alkaloids; polyphenols (Gbogbo et al., 2013). .All these compounds are well known for their antimicrobial activities. In addition of these antimicrobial compounds most of the cited families have been reported to contain flavonoids, a class of chemical compounds known to possess anti-oxidant properties that prevent free radical generation and tissue damage associated with the onset of dermatosis. Also these plant families are endowed with terpenoids, a secondary metabolite that enhance and maintain the immunity of the patient.

The most cited plants are: Pteleopsis suberosa; Hymenocardia acida; Blighia sapida; Pterocarpus erinaceus; Daniella oliveri; ; Ficus sur; Sarcocephalus latifolius ; Pseudocedrela kotschyi; Vernonia cinerea. An ethnobotanical survey carried out by Tittikpina and co-workers in the same region at the prefecture of Tchamba has shown that the two leading plants used against Bacterial and fungal infections were Pterocarpus erinaceus and Daniella oliveri. 
Different parts of medicinal plants were used to treat fungal infections. Among the different plant parts, leaves were most commonly used $(43,24 \%)$ for the treatment of diseases followed by roots $(18,91 \%)$; aerial parts $(16,21 \%)$; barks $(13,51 \%)$; whole plants $(8,10 \%)$; fruits $(5,40 \%)$. The stem apexes, latexes and almonds $(2,70)$ each one. Results with similar trend have been reported by other researchers (Telefo et al., 2011; Gbadamosi et al., 2014). The plant leaves are important ingredients in traditional treatment of various diseases as it features as a component in many herbal preparation. As the main photosynthetic organs, leaves might contain photosynthates which could be responsible for medicinal values (Ghorbani, 2005; Anup et al., 2014). Also, collection of leaves and then using them as medicine is very easy as compared to roots, flowers and fruits (Telefo et al., 2011; Giday et al., 2009). Another reason of using leaves could be concerning conservation of the plants as digging out roots might be the cause of death of the plant and putting the species in a vulnerable condition (Batawila, 2002; Rehecho et al., 2011)

Most preparations are made with water as a solvent and the decoction is generally the method of choice $(67,56 \%)$. The preference of this mode of preparation is reported by many authors (Abouri et al., 2012: Gbekle et al., 2015). The great majority of the remedies were taken orally (78 \%). External application were also employed, and may consist, generally, in a local application to the affected part.

\section{Conclusion}

The survey has added more to the existing discoveries of the relevance of plants and its usefulness in the treatment of fungal infections among the residents of Prefecture de Sotouboua in Central region of Togo. The different plants clamed in this study need to be evaluated through a phytochemical, pharmacological and toxicological investigation to discover their active compounds.

\section{References:}

1. Abouri, M., El Mousadik, A., Msanda, F., Boubaker, H., Baha, S., and Cherifi, K. (2012). An ethnobotanical survey of medicinal plants used in the Tata Province, Morocco. Int.J. Med. Plants.Res., 1 (7): 099123.

2. Ahmed, S.S., and Husain, S.Z. (2008). Ethno Medicinal survey of plants from Salt Range (Kallar Kahar) of Pakistan Pak. J. Bot., 40(3): 1005-1011.

3. Akpagana, K. (2013). Evaluation des propriétés antimicrobiennes de Pterocarpus erinaceus Poir (Faboïdeae) et Daniellia oliveri (Rolfe) 
Hutch. et Dalz (Caesalpinoïdeae), utilisées en médecine traditionnelle au Togo. Int. J. Biol. Chem. Sci., 7(4): 1586-1594.

4. Alqasim, A. M., Gabriel, O., Is-Haq, I. U. (2013). Plant remedies practiced by Keffi People in the management of Dermatosis. J. Med. Plants Stud., 1(5): 112-118.

5. Anup, K.D., Mamun, O.R., Shalahuddin, M., Mamunur, R. (2014). Ethnobotanical survey of medicinal plants used by traditional health practitioners and indigenous people in different districts of Chittagong division, Banglades. IJPSI, 3(7): 01-07.

6. Batawila, K. (2002). Diversité, écologie et propriétés antifongiques des Combretaceae du Togo. Acta Botanica Gallica, 149:4, 515-516.

7. Betti, J. L., et Mebere, Y.S .R. (2011). Contribution à la connaissance des produits forestiers non ligneux du parc de Kalamaloué, Extrême nord Cameroun: les plantes alimentaires. Int. J. Biol. Chem. Sci., 5(1): 291-303.

8. Borman, A.M., Campbell, C.K., Fraser, M., Johnson, E.M., 2007. Analysis of the der-matophyte species isolated in the British Isles between 1980 and 2005 and review of worldwide dermatophyte trends over the last three decades. Med.Mycol., 45, 131-141.

9. Cowan, M.M. (1999). Plant Products as Antimicrobial Agents. Clin. Microbiol. Rev., 12(4):564 - 582.

10. Gbadamosi, I.T., and Egunyomi, A. (2014). Ethnobotanical survey of plants used for the treatment and management of sexually transmitted infections in Ibadan, Nigeria. Ethnobotany Research \& Applications, 12:659-669.

11. Gbekley, E. H., Karou, D. S., Gnoula, C., Agbodeka, K., Anani, K., Tchacondo T., Agbonon A., Batawila K., Simpore, J. (2015). Étude ethnobotanique des plantes utilisées dans le traitement du diabète dans la médecine traditionnelle de la région Maritime du Togo. PAMJ, 20:437.

12. Gbogbo, K.A., Agban, A., Woegan, A.Y., Amana, E.K., Hoekou, Y.P., Batawila, K. (2013). Evaluation de l'activité antimicrobienne de Momordica charantia (cucurbitaceae), Psidium guajava (myrtaceae) et Pteleopsis suberosa (Combretaceae). ESJ, vol.9, No.36.

13. Ghorbani, A. (2005). Studies in pharmaceutical ethnobotany in the region of Turkmen Sahra, North of Iran (part 1): general results. J. Ethnopharmacol., 102, 58-68.

14. Giday, M., Asfaw, Z., and Woldu, Z. (2009). Medicinal plants of the Meinit ethnic group of Ethiopia: an ethnobotanical study. $J$. Ethnopharmacol., 124, 513-521.

15. Gruca, M., Yu, W., Amoateng, P., Nielsen, M. A., Poulsen, T. B., Balslev, H. (2015). Ethnomedicinal survey and in vitro anti- 
plasmodial activity of the palm Borassus aethiopum Mart. $J$. Ethnopharmacol. 4 (175) 356-69

16. Maloueki, U., Kapetshi, J., Kabena, N. O., Ndimbo, K. S., Ngbolua, K. J., Mbomba, N.B., et al. (2015). Activités antimicrobiennes et antioxydantes des extraits aqueux totaux des fruits de Dialium corbisieri et Dialium gossweilerii (Fabaceae-Caesalpinioideae), consommés par les bonobos, Bolobo, République Démocratique du Congo. Int. J. Biol. Chem. Sci., 9 (2)

17. Ngono, N.RA., Koanga, M. M. L., Tchinda, T. A., Magnifouet, N. H., Motso, C. R., Mballa, B. Z., Ebelle, E. M., Ndifor, F., Biyiti, L., Amvam, Z. H. (2001). Ethnobotanical survey of some Cameroonian plants used for treatment of viral diseases. Afr J Plant Sci., 5 (1): 1521

18. Otang, W. M., Grierson, D. S., Ndip, R. N. (2012). Ethnobotanical survey of medicinal plants used in the management of opportunistic fungal infections in HIV/AIDS patients in the Amathole District of the Eastern Cape Province, South Africa. J. Med. Plants Res. 6(11), 2071.

19. Pfaller,M.A., Messer,S. A., Moet,G. J., R. N. Jones, N.R. and M. Castanheira, M. (2011). Candida bloodstream infections: comparison of species distribution and resistance to Echinocandin and azole antifungal agents in Intensive Care Unit (ICU) and non-ICU settings in the SENTRY Antimicrobial Surveillance Program (2008-2009), IJAA, 38 (1): 65-69.

20. Pushpangadan, P., Atal, C. K. (1984). Ethno-medicobotanical investigations in Kerala- some primitive tribal of Western Ghats and their herbal medicine. J. Ethnopharmacol., 11(1):59 -77.

21. Raveesha N. K. A (2015). Ethnobotanical survey and scientific validation of medicinal plants used in the treatment of fungal infections in agumbe region of western ghats, India. Int $J$ Pharm Pharm Sci., 7 (4): 273-277

22. Rehecho S, Uriarte-Pueyo I, Calvo J, Vivas L.A and M. I. Calvo M.I, (2011) Ethnopharmacological survey of medicinal plants in NorYauyos, a part of the Landscape Reserve Nor-Yauyos-Cochas, Peru. J.Ethnopharmacol. 133, 75-85.

23. Sheher, B. M., Noshia, A., Muhammad, S., Nukhba, I., and Nigam, H. (2013). Ethnobotanical literature survey of plants used to cure skin diseases, Pakistan. WASJ, 27 (4): 474-478.

24. Simbo, D. J. (2010). An ethnobotanical survey of medicinal plants in Babungo, Northwest Region, Cameroon. J. Ethnobiol Ethnomed., 6:8. 25. Shosan, L. O., Fawibe, O.O., Ajiboye, A.A., Abeegunrin, T.A. and Agboola, D.A. (2014). Ethnobotanical survey of medicinal plants 
used in curing some diseases in infants in Abeokuta south local government area of Ogun State, Nigeria. AJPS., 5, 3258-3268.

26. Telefo, P. B., Lienou, L.L., Yemele, M.D., Lemfack, M.C., Mouokeu, C., Goka, C.S., Tagne, S.R. and Moundipa, F. P. ( 2011). Ethnopharmacological survey of plants used for the treatment of female infertility in Baham, Cameroon. J. Ethnopharmacol. 136, 178187.

27. Tittikpina, N. K., Agban, A., Gbogbo, K.A., Hoekou, Y. P., Pereki, H., Batawila, K. et

28. Vicente, M., Basilio, A., Cabello, A. and Pelaez, F. (2003). Microbial natural products as a source of antifungals. Clin. Microbiol. Infect. 9, $15-32$.

29. WHO (2000): General Guidelines for Methodologies on Research and Evaluation of Traditional Medicine. Switzerland: Geneva, 1 - 80. 